\title{
NUTRITION AMBASSADOR COMPETITION AS A METHOD TO IMPROVE NUTRITION KNOWLEDGE OF HIGH SCHOOL STUDENTS
}

\author{
Febry Harissa Surbakti ${ }^{*}$, Khoirul Anwar ${ }^{1}$, Aviani Harvika ${ }^{2}$, Megah Stefani ${ }^{1}$, Hardinsyah Hardinsyah ${ }^{2}$ \\ ${ }^{1}$ Nutrition Program, University of Sahid Jakarta, ${ }^{2}$ Food and Nutrition Society of Indonesia (PERGIZI PANGAN \\ Indonesia) \\ *febry_harissa@usahid.ac.id
}

\begin{abstract}
Indonesia, a developing country, is still facing nutrition problems caused by lack of access to food and nutrition knowledge. Adolescents play an important role in a long term preventing of nutrition problem. Competition and award are ways of increasing adolescent interest and motivation in gaining nutrition knowledge. Therefore, the purpose of this empowerment program is to improve nutrition capacity og high school students (HSS) through a nutrition ambassador competition and award. The selection of nutrition ambassador candidates is carried out through written selection for $2^{\text {nd }}$ grade HSS in 5 high schools (HS) in each selected city oN 8 cities of Indonesia. Five best couples from each HS then follow a second stage written selection at city level. Finally, the five best couple nominated from the second stage were then interviewed to determine the best three couple as nutrition ambassadors for every city. The result showed about 200 HSS involved as the candidates: and they read the balance nutrition guidebook from ministry of health as an online compulsory reading book which was uploaded in the web of PERGIZI PANGAN Indonesia. The mean nutrition knowledge score of the NA was 65.4 \pm 12.9 which categorized as moderate level. This activity was appreciated by school principals and by local health district office heads. The nutrition ambassadors helped local health office to educate nutrition to HSS in each city. Now with the assistance from PERGIZI PANGAN Indonesia, they are sharing nutrition information and experience via WhatsApp Group. This implies that nutrition ambassador competition and award could be developed to improve nutrition capacity of HSS.
\end{abstract}

Keywords: adolescent nutrition, balance nutrition, nutrition ambassador, nutrition knowledge,

\section{INTRODUCTION}

In Indonesia, the teenage population is a fairly large population of 66.3 million inhabitants of adolescents aged 10-24 years of the total population of 258.7 million (BadanPusatStatistik, 2017). Teenagers are the nation's assets that create better future generations, one of which is to inspire and motivate nutritional messages and healthy living. Riskesdas (2013) says that Indonesia is facing two nutritional problems namely lack and excess nutrition in all age groups and sexes, $26.1 \%$ of Indonesian people are classified as less active physical activity. In Indonesia, the prevalence of children under five who experience malnutrition, short and fat is $19.6 \%, 37.2$, and $11.9 \%$. Whereas in the age of school children (5-12 years) the prevalence of children who experienced thin, short and obese was $11.2 \%$, $30.7 \%$ and $18.8 \%$. Whereas with good nutritional status through balanced nutrition it is very important to form a high level of health, intelligence and work productivity. Good nutritional status is determined by food consumption both in quality and quantity, adequate physical activity, and a healthy living environment. Therefore, it is very important to apply balanced nutrition and hygienic and healthy living behavior to realize good nutritional status.

According to Tanti (2013) Excessive appetite for food in certain teenagers causes nutritional needs not to be met, this situation is related to "fashion" such as fast food and fast food eating habits. According to WHO (2007), lifestyle and the influence of the surrounding environment on adolescents have an influence in choosing the food they will eat, they also often try new foods, one of which is fast food. Based on the above problems, the researchers are interested in holding a selection of balanced nutrition ambassadors to be expected to inspire and motivate nutrition messages and healthy living in the wider community through social media. 
THEORETICAL FRAMEWORK

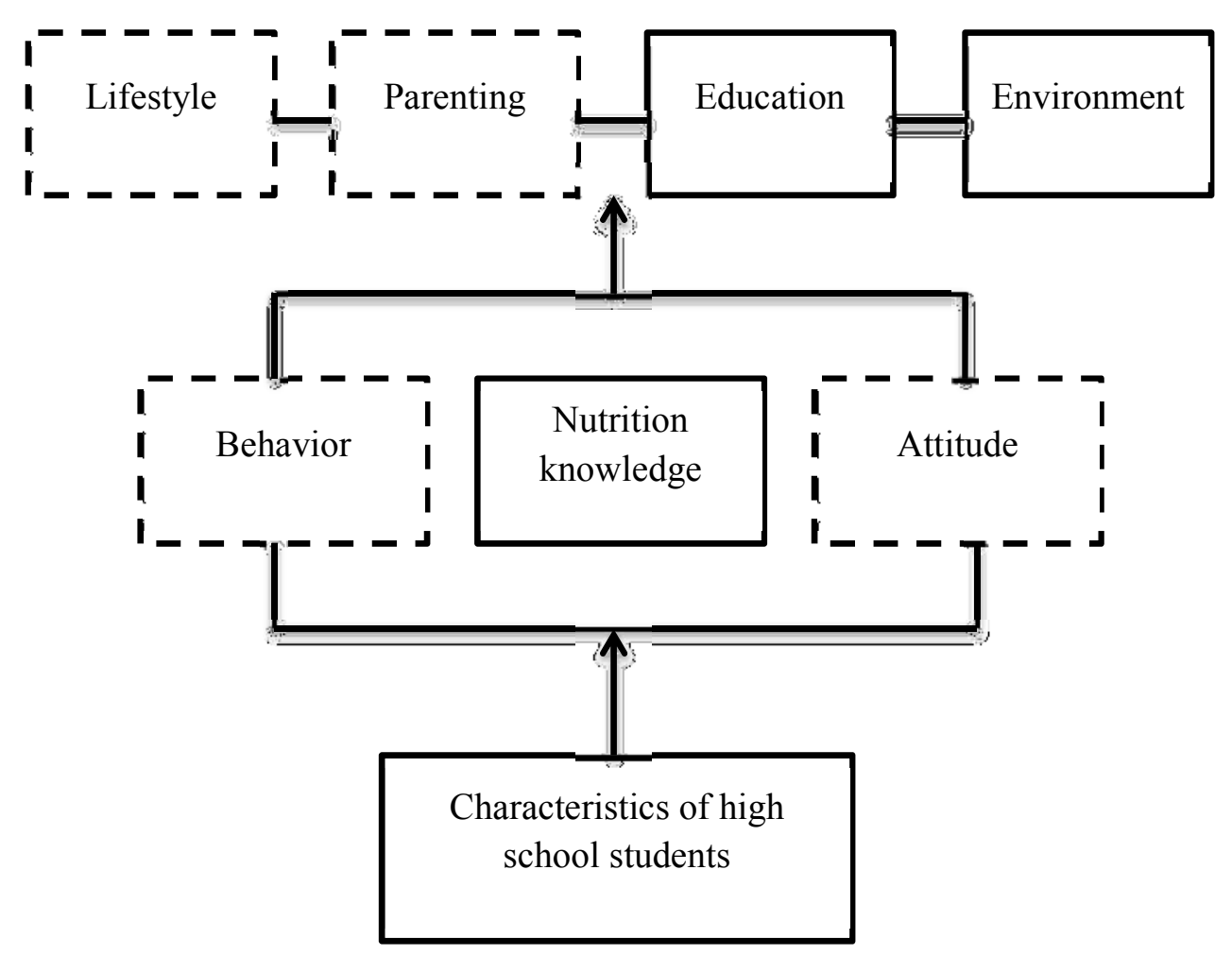

Figure 1. Frame work nutrition ambassador competition as a method to improve nutrition knowledge of high school students

\section{METHOD}

\section{Subject}

Participants in the selection of Balanced Nutrition Ambassadors consisted of 5 selected high schools in each location with a total of 2000 students who were then selected eight pairs of balanced nutrition ambassadors. All winners are currently joined in a WhatsApp group for communication by PERGIZI PANGAN and related parties.

\section{Mechanism}

This balanced nutrition ambassador selection activity was held in August - October 2016 at each campus (Palu Polytechnic, UPI, Riau Polytechnic, UNIMUS, UNSOED, IPB, UPN). The implementation of the selection of balanced nutrition ambassadors was carried out through three stages of selection, namely the first selection was done in writing in each selected high school in each city to select the best 3 pairs from each high school, followed by a second selection in writing on the host campus and interviews for 3 to 5 couples. finalist Ambassador of Balanced Nutrition. 


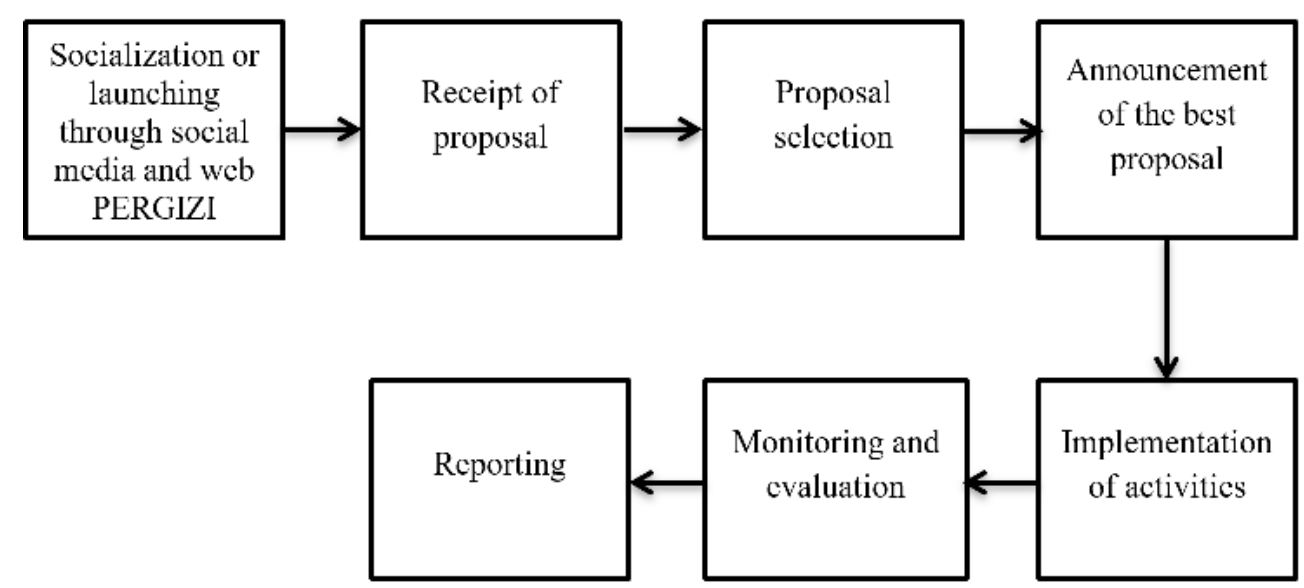

Figure 2. Activity Flow

\section{RESULT AND DISCUSSION}

Table 1. Level of nutritional knowledge ability

\begin{tabular}{|c|c|c|r|}
\hline Nutrional Knowledge & $\mathrm{n}$ & Mean \pm SD & $\%$ \\
\hline Less & 20 & $67.40 \pm 8.20$ & 29.41176 \\
\hline Moderate & 32 & $49.75 \pm 4.83$ & 47.05882 \\
\hline Good & 16 & $80.81 \pm 4.47$ & 23.52941 \\
\hline Total & 68 & $65.36 \pm 12.88$ & 100 \\
\hline
\end{tabular}

Nutrition knowledge is an important prerequisite for changes in nutrition attitudes and behaviors. According to Khomsan (2009) the value of knowledge of nutrition is "Good" as follows $>75 \%$, "moderate" 56-75\% and "less" $<56 \%$. Based on the table above, $1 / 3$ of the total respondents were selected as many as 68 balanced nutrition ambassadors. A total of $47.05 \%$ of ambassadors had "moderate" nutrition knowledge with an average of $49.75 \pm 4.83$, while only $29.41 \%$ of ambassadors had "Less" nutritional knowledge with an average of $8.20 \pm 67.40$ and as many as $23.52 \%$ ambassadors who had nutritional knowledge " Good "with an average of $4.47 \pm 80.81$.

According to Wawan (2011), the factors that influence nutritional knowledge are internal factors namely age, according to Notoatmodjo (2007) the more age the ability and strength level of a person will be more mature in thinking and working. while external factors consisting of educational factors, according to Sunaryo (2004) the higher the education of a person, the easier it is to receive information so that more knowledge is possessed, work, according to Notoatmodjo (2007) the existence of someone's work will take a lot of time and effort to complete the work which is considered important and requires attention, so that busy people have little time to obtain information and the environment and social culture.

\section{CONCLUSION}

Based on the results of the study the selection of balanced nutrition ambassadors in high school children was considered successful because almost half of the respondents were 68 selected balanced nutrition ambassadors, 47.05\% had "Enough" nutritional knowledge ability with an average of $49.75 \pm$ 4.83 expected from nutritional knowledge owned by ambassadors balanced nutrition can provide infographics on social media nutrition messages and healthy living. 


\section{REFERENCES}

Badan Pusat Statistik. (2017). Penduduk Menurut Kelompok Umur dan Jenis Kelamin. Diakses 4 September 2018. http://bps.go.id

Khomsan, A. (2010). Pangan Dan Gizi Untuk Kesehatan. Jakarta : PT. Raja Grafindo Persada.

Notoatmodjo, S. (2007). Promosi Kesehatan dan Ilmu Perilaku. Jakarta : Rineka Cipta

Sunaryo.(2004). Psikologi untuk Keperawatan. Jakarta: EGC

Marina, T.Y. (2013). Hubungan Pengetahuan Gizi dengan Kebiasaan Makan Peserta Didik Kelas XI Jasa Boga SMK N 6 Yogyakarta. Skripsi. Yogyakarta. Universitas Negeri Yogyakarta.

Wawan. (2011). Teori dan Pengukuran Pengetahuan Sikap dan Perilaku Manusia. Yogyakarta: Nuha Medika

WHO. (2007). Growth Reference 5-19 Year. 7 Febuari (2018). http://www.who.int/growthref/who2007_bmi_for_age/eg/index.html. 